\title{
Sønderjylland 1923.
}

Af Thade Petersen.

For Aarene 1888-1893 skrev Gustav Johannsen i sin Tid her i Aarbøgerne en Oversigt over hvert Aars Oplcvelser i Sønderjylland. I disse Oversigter trak han de store Linjer i Aarets Begivenheder op, som kun den kan gøre det, der selv er levende og interesseret med i dem. Men han indskrænkede sig i leglen til det politiske og nationale, og han gik ikke gerne meget i Enkeltheder.

Fra 1901-1909 har Tidsskriftet bragt en Dagshistorie i Tidsfolge. Den byder flere daterede Enkeltheder og favner videre, end Gustav Johannsens Oversigter. Den er saaledes et godt Hjælpemiddel for Granskningen af vor Historie. Derimod har den ikke det, der gjorde Gustav Johannsens Oversigter til kær Læsning for den jævne Læser. De store Linjer i Begivenliedernes Gang træder ikke klart frem.

Naar jeg nu fortsætter den to Gange paabegyndte Række Oversigter over hvert enkelt Aars Oplevelser i Soncierjylland, vil jeg prove paa at forene Fortrinnene ved de to tidligere Fremgangsmaader, derved, at jeg giver en Oversigt over Begivenhederne samlede efter bestemte Linjer og for hver Begivenhed henviser til, hvor den er bleven udførligere omtalt i Pressen eller andre Steder. Jeg haaber derved at kunne give et sammenhængende Billede af Livet her 
i Landsdelen, der vel ikke kan faa den Førstehaandsværdi, som Gustav Johannsens i sin Tid, men maaske nok blive noget mere udpenslet til forskellige sider, og som ved Siden deraf kan blive en lignende Hjælp. for dem, der vil sysselsætte sig med bestemte Grene af Livet her, til at faa fat $i$ de Oplysninger om det, der kan findes $i$ de samtidige Offentliggarelser. Jeg har - i alle Tilfælde for i Aar - væsentligt maattet holde mig til Dagspressen, der bringer det mest spredte Stof, og inden for den igen maattet nojes med et enkelt Blad. Jeg har dertil valgt "Hejmdal" som det, jeg havde bedst Oversigt over og lettest Adgang til, og som vel ogsaa paa Grund af sin spredte Holderkreds er et af de mindst egnsprægede. Jeg gaar derved ud fra, at naar en Gransker bare ved, til hvilken Tid et Sporgsmaal er paa Tale, saa kan han ogsaa let finde det - i dets forskellige Belysninger - i de andre Blade. Hvor en Begivenhed af sig selv medforer bestemt Datering, gives der i Heglen ingen Henvisning. Der vil selve Datumet være Vejledning nok til at finde den Oplysning om den, de forskellige Blade har bragt samtidig eller ganske kort Tid derefter. Hvor en saadan Datering ikke forekommer, er der sat Datum i Klammer, og det betyder da, at Spørgsmaalet er paa Tale i "Hejmdal " for den Dag.

Vi begynder nu med en Oversigt over 1923. Maaske vi saa senere kan bringe en for Aarene 1910-14 og 1918-22. 1900 findes »Haandbog $i$ det nordslesvigske Spørgsmaals Historie«, og for Krigstiden vil det være vanskeligt at give noget, af Værdi af den Slags.

Jeg tør ikke paastaa, at de Henvisninger, jeg har givet, peger direkte paa enhver Oplysning af 
Tærdi, men jeg tror at turde sige, at der ved Hjælp af dem kan findes saa meget, at de vil kunne anses for et brugbart $\mathrm{Hjælpemiddel.} \mathrm{Den,} \mathrm{for} \mathrm{hvem} \mathrm{det} \mathrm{gæl-}$ der om at finde a ll e Oplysninger om en Sag, vil ikke sky Arbejdet ved at opsuge ogsaa det, der er overset og kunne drage Nytte af de Holdepunkter, der er givet.

\section{3.}

\section{Grænsen.}

Efter at Grænsen er afstukken og godkendt af de danske og tyske lovgivende Forsamlinger som den lovmæssige Grænse, er den ikke mere noget politisk Sporgsmaal. Den »ligger fast", saadan som den er. I den offentlige Droftelse kommer den imidlertid endnu til at spille en Rolle, og de politiske Faktorer paa begge sider nødes nu og da til at tage Stilling til den.

Den 7. Januar faldt der paa et tysk-nationalt Partimøde i Flensborg skarpe Udtalelser om Grænsesporgsmaalet, og den 12. talte Overborgmester Todsen fra Flensborg paa Slesvigholstenerforbundets Aarsmøde i Bredsted om, at Danskerne ønskede at besætte Landet ned til Ejderen, men Grænsen skulde tværtimod flyttes mod Nord. Han benægter imidlertid senere at have sagt saadan (23.1.)

Paa Grænseforeningens Møde i Sønderborg den 21. 1. taltes der om Kamp ved Grænsen, men ikke om Flytuing af den.

I Begyndelsen af Marts fremkom et Rygte om, at der $\mathrm{i}$ visse Kredse albejdedes for Oprettelsen af e $n$ s elvstundig stat, der skulde omfatte en Del af Nordslesvig, hele Sydslesvig og Holsten indtil Kamalen. (9. 3.). Gaardejer Cornelius Petersen i Vester 
Anflod, hvis Navn i "Hejmdal" var sat i Forbindelse med denne Sag, rejste Klage mod Bladet for Fornærmelse, dog uden Resultat (10. 3., 27. 3., 30. 5., 21. 6., 25., 21j. og 27.6.) Rygtet om denne Plan førte ogsaa til Hussøgning hos en Række fremtrædende Mænd i Sydslesvig, men ligeledes uden Resultat (Grænsebogen S. 251-54.)

I April sysselsatte Forholdene ved Grænsen den preussiske Landdag, idet $L$ and dag $\mathrm{s} m$ and $H$ of $f$ holdt en Tale om den danske Bevægelse i Mellem- og Sydslesvig (12. 4.), og de tysk-nationale indbragte en Forespørgsel vedrørende denne (25. 4.). Denne Forespørgsel gav den preussiske Ministerpræsident Braun Anledning til at udtale sig i Landdagen om Grænsespørgsmaalet og den danske Bevægelse. Han viste sig imidlertid meget daarligt underrettet paa flere Punkter. Da Grænseforeningen den 27. 5. holdt Delegeretmøde i Sønderborg, gjorde den Indsigelse mod hans Fremstilling. Det samme gjorde Undervisningsminister Appel i et Interview med Hensyn til hans Fremstilling af Skoleforholdene sydfor Grænsen (28. 5.) og endelig kom "Dansk Skoleforening i Flensborg med en Indsigelse (31. 5.) Ved Genforeningsfesten i Aabenraa 15. 6. talte H. P. Hanssen i den Anledning om Grænsen og paaviste, at den faktisk bliver trukket stadig skarpere og fastere op.

Som en Efterdønning af det Røre, Forhandlingerne $\mathrm{i}$ den preussiske Landdag afstedkom, maa det betragtes, naar tidligere Rigskansler Dr. $M$ i c h a e l i s under et Besøg her i Landet, adspurgt af "Fyns Venstreblad", udtalte: "Den nuværende dansk-tyske Grænse ligger fast" og "Vi anerkender Afstemningen« (12. 7.) Trængt af Altyskerne søgte ogsaa han senere at afsvække sine Udtalelser. 
Den 13. 7. holdtes i Slesvig et af 2000 Mennesker besøgt Kampmode mod "Ejderdanskerne" (16. 7.), hvor der faldt skarpe Udtalelserne om Grænsedragningen.

Nyt Liv fik Grænsediskussionen ved, at den konservative Generalkorrespondance bragte en Artikel-

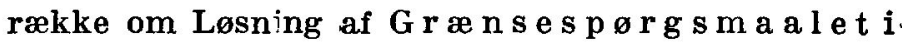
t o T e m p i (3., 8., 12. 9,) Ret velgørende var det under disse Forhold, naar "Schleswig-Holsteiner-Bund" $i$ et Opraab vel sagde, at det vilde modsatte sig "yderligere Afstaaelse af slesvig-holstensk Jord til Danmark" - hvad ingen tænkte paa - men ikke talte om Grænseflytning nordpaa (23. 10.)

En ny Farce traadte denne Diskussion ind $\mathbf{i}$, da tyske og danske Socialdemokrater paa et Mode i Flensborg den 25. 11. traf en Overensk o m st, hvori de fra begge Sider udtaler, at de anerkender den bestaaende Grænse og vil bekæmpe enhver Irredenta paa begge Sider (29.11.) Det gav de tysknationale Anledning til at stille en ny Forespørgsel $i$ den preuss'ske Landdag (17. 12.) Drøftelsen af dette Spørgsmaal er naturligvis ikke endt med Aaret.

Et Spørgsmaal, der staar i Forbindelse med Grænsedragningen, er Forde $\mathrm{ling}$ e $\mathrm{n}$ a $\mathrm{f}$ of $\mathrm{f}$ e $\mathrm{nt}$ lig Formue og Gæld mellem Danmarkog T y sk l a nd. Om den Kommission, der, var nedsat i dette Øjemed, kunde Indenrigsministeriet i Begyndelsen af Aaret meddele, at den havde lost en Række betydningsfulde Spørgsmaal (16. 1.). Ogsaa Fordelingen af offentlige Forsikringsbyrder og -rettigheder samt Pensonering hører her hen. Blandt de Spørgsmaal der har været arbejdet paa endnu i 1923, er den tyske Privatfunktionærforsikring, der om-- 
fattede 900 Personer i Nordslesvig med en Sum af 600,000 M. (5. 7.)

I denne Forbindelse maa nævnes, at Markkreditorerne i Nordslesvig har ved Markens Sammenbrud tabt 357 Millioner $\mathrm{Kr}$., hvoraf 59 Mill. er bleven erstattet af Staten. Nordslesvig som Helhed antages at have tabt 120 Mill. Kr. Dets Greld udad paa 100 Mill. Guldmark i 1914 er vokset til 220 Mill. Kroner i 1923. 3. 3. vedtog Sparekasserne at opsige alle Markindskud, og Opsigelsen skete mod Slutningen af Marts.

Nordslesvigs Finansiering har kostet den danske Stat omtrent 500 Millioner Kroner (23. 8. Grb. 31148.) Valutareguleringen kostete omtrent 60 Mill. (2. 1.) Rentereguleringen har været utilfredsstillende (7. 3.) En Omregning af Markhypotekerne kan ikke ventes (23. 4.) En af de uheldige Kronelaanssager fra Overgangstiden afgjordes 14. Juni for Højesteret, idet Gaardhandler C. C. Dall i Snogbæk blev dømt til at tilbagebetale 200,000 M., han havde laant af Hestehandler Schmidt i Kolding til Kurs 63 (14. 6., 15. 6.) Tïl Overgangsfremtoningerne hører ogsaa en Højesteretsdom, hvorved Domæneforpagter Schwerdtfeger dømtes til at fratræde en Forpagtning af Rønhave, som han i Juni 1919 havde faaet forlænget indtil 1940 (1. 12.)

Den sønderjydske Fond, hvis Bestyrelse 11. 1. valgte Professor Ehlers til Formand og Folketingsmand Mads Gram til Næstformand, har indtil 31. 12. 21. indsamlet 11,890,274 Kr. i Penge og Naturalier. Deraf var der 1. 1. 23. 3,771,037 Kr. i Behold. (17. 3., 8. 12.) For 1924 har Fonden budgetteret $473,120 \mathrm{Kr}$. til Nordslesvig og $139,818 \mathrm{Kr}$. til Sydslesvig (15. 12.)

En La a n asse, der traadte i Virksomhed 
straks ved Genforeningen, afsluttede med 1922 sin anden og sidste Driftsperiode. Den har ialt ydet 4497 Laan paa tilsammen $11,376,150 \mathrm{Kr}$. i den almindelige Afdeling og 467 Laan paa ialt $855,900 \mathrm{Kr}$. i Invalideafdelingen (5. 4.)

Et mange Gange større Antal havde Del i Alderdoms- og Invalideforsikringen. For dens Vedkommende blev Danmarks Del 3 Millioner M. (9. 3.) Vedrorende de militære Invalider, der var bleven danske Statsborgere, fremsattes der 13. 3. et Lovforslag $\mathbf{i}$ Folketinget (19. 3.).

Vedrørende Ulykkesforsikringen frensatte en Deputation 22. 2. et Andragende til Indenrigsministeren om Endr:nger i Loven (6. 1., 22. 2., 24. 2.).

Til Grænseforhold hører ogsaa det, at $\mathrm{T}$ j e n est ef olk S y d f r a er sxgt her over i saa stort Tal, at det har voldt Bekymringer. I Haderslev Amt fandtes i Efteraaret 1223 udenlandske Tjenestefolk (28. 10.) Nærmere ved Grænsen er Tallene forholdsvis meget større, ialt var der i Dag mellem (; og 10,000 i hele Nordslesvig. (11. 5., 22. 5., 10. 6., 20. (i.)

Ogsaa $F æ r d s l$ e n ov er Gr $æ n$ s e n maa nævnes her, navnlig for saa vidt som den falder udenfor almindeligt Samkvem. Den stærke Strøm Syd paa for at købe op, .var i 1922 reduceret stærkt, da de tyske Priser steg, ved Besættelsen af Ruhr tog den lidt Fart igen, dog kun for en kort Tid (13. 2., 23. 2.), og i Begyndelsen af 1923 vendte Strømmen, idet Priserne nu var billigere Nord for Grænsen. Opkøberne kom derfor nu Syd fra over denne (3. 3., 2(i. 4.)

Til Færdslen over Grænsen hører ogsaa den ulovlige. Den volder Grænsepolitiet stort Besvær og Grænseamterne store Omkostninger. Aabenraa Amt. 
har alene $30,000 \mathrm{Kr}$. aarlig Udgift til Hjemsendelse og Straffefuldbyrdelse af ulovlige Grænseoverløbere (15. 3.)

\section{Nationalt Liv ved Grænsen.}

Mere end de for omtalte Meningsytringer om selve Grænsen betyder det, at nationalt Liv rorer sig paa begge Sider af Grænsen og slaar i stærke Bolger hen over den saaledes, at der ved Siden af det danske findes tysk nationalt Røre Nord for den og ved Siden af det tyske dansk Syd for den og afstedkommer stadig Kamp.

Som Udtryk for, at de agter at holde den nationale Kamp gaaende Nord for Grænsen, opfordrede $\mathrm{Ty}$ skerne i Begyndelsen af Aaret tysknationale Optanter til at søge Pladser og bosatte sig her oppe. (19. 1.) Denne Opfordring er aabenbart bleven fulgt i stort Maal. Indtil den 12. 12. var der fra Nordslesvig kun afgivet 47 Optionserklæringer for Tyskland, hvoraf endda kun 6 var gjort gyldige ved Flytning til Tyskland (8. 1. 24). Derimod har mange fra Sydslesvig opteret for Danmark. De er dog langtfra alle tysksindede og tysktalende.

Efter at have sundet sig paa det bedøvende Slag ved Folkeafstemningen i 1920, begyndte $\mathrm{T}$ y s k e r n e i Nordslesvig efterhaanden at udnytte al den Frihed, den danske Lovgivning giver dem, til Fremme af deres Formaal (Sønderj. Aarb. 1923 S. 142-176). I 1923 har de 24. 3. dannet en Frimenigh ed eller rettere en Afdeling af den slesvigholstenske Landskirke - i Tinglev (28. 3.) med Pastor Gottfriedsen, der 29. 4. ordineredes af Generalsuperintendent Petersen, som Præst. En lignende Menighed dannedes senere i Logumkloster med Pastor Boyens 
Præst. Ved den Lejlighed viser det sig, at der bestaar et »tysk Kirkeudvalg for Nordslesvig" (8. 8.).

I Toftlund ansøgte i Efteraaret 55 Underskrivere, "der til Dels ikke er det danske Sprog mægtig" om tysk Gudstjeneste en Gang maanedlig og paa alle anden Helligdage (8. 11.). Anden Juledag og 27. 1. fik de Lov til, men ikke til regelmæssige Gudstjenester (21. 11., 1. 12.). I Tinglev mente den tyske Menighed endog at kunne gore Krav paa et Skolelokalé til Konfirmandundervisning (10. 11.).

Ved Aarets Begyndelse fandtes der 11 tys ke $V$ andrel ærere og -lærerinder i Nordslesvig (3. 1.) og 7 tyske Privatskoler (29. 11., 1. 12.) foruden, at der findes mange tyske Folkeskoleklasser og gives tysk Sprogundervisning i mange ellers danske Skoler (S. Aarb. 1923 S. 157). Alligevel stiller Tyskerne endnu stadig større Krav. En Deputation, der 3. 11. 22 havde Foretrade hos Ministeren, krævede bl. a. tysk Folkeskole, hvor 20 ; af de V:elgere, der har Børn under 14 Aar, kræver det, en tysk Skolekommission for hver tysk Skole og mindst 5 Timers tysk Religions- og Sprogundervisning ugentlig, hvor det ønskes (7. 2.). Til Vandrelærervirksomheden blev der i 1922 indsamlet $550,000 \mathrm{Mk}$. Syd for Grænsen (10. 3.). For Resten maatte Pastor Schmidt under en Forhandling i Folketinget i April vedgaa, at Tyskerne havde opnaaet bedre Forhold. Dog ønskede han endnu lettere Adgang for dem til at lære tysk (11. 4.).

Mod Slutningen af Aaret vedtoges det, at den tyske Pigehøjskole i Tinglev ogsaa skal afholde 8 Dages Kursus for unge Landmænd (13. 12.).

Til Støtte for sligt Arbejde har man til en saa- 
kaldt "Jugendspende Nordschleswig" indsamlet 21,133,498 Mk. i Sydslesvig og Holsten. Tyskerne i Nordslesvig har selv skaffet 50,000 Kr. til det ved frivilligt offer af ca. $1{ }_{0}$ af deres Indtægt. Dette har desuden givet 300,000 Kr. til nodlidende i Tyskland (27. 12.).

Mod Slutningen af Aaret begyndte et $\mathrm{t}$ y s k O p$\mathrm{k} ø \mathrm{~b}$ a f $\mathrm{E} \mathrm{j}$ e $\mathrm{n} \mathrm{d}$ o m me i Nordslesv'g (11. 12, 15. 12., 17. 12.), dels af nationalpolitiske Grunde, dels for at faa Kapitalen anbragt udenfor Tyskland.

Til en Fest paa Knivshjerg 16, 9. samlede de 2-3000 Deltagere.

Fra dansk Side er der selvfolgelig ikke lagt de tyske Bestræbelser for Udfoldelse af tysk Aandsliv nogen Hindring i Vejen, mens man dog ikke har kunnet gaa med til at tilfredsstille alle de Krav, der stilledes til offentlige Institutioner og Midler. Saa frit har der ikke kunnet arbejdes for Bevarelsen af dansk Sprog og. Aandsliv Syd for Græns e n.

Dansk Menighedsliv i Flensborg er nu samlet om Menighedssalen "Ansgar" alene. Ved Pinsetide ophørte de danske Gudstjenester i Helligaandskirken indtil videre af Mangel paa Tilhørere. I "Ansgar" derimod trives det godt (10. 9.). I Foraaret konfirmeredes f. Eks. 118 unge $\bmod 90$ i 1922 (Grb. S. 42).

I Valsbøl indviede Frimenighedspræst Niels Dael fra Høve 2. 12. en Kirkesal for en lille Kreds, der helt vil være Frimenighed.

Ogsaa i Slesvig samles en Kreds om Pastor Noak fra Flensborg. Overfor Sognepræsterne der $\mathbf{i}$ Byen er han gaaet ind paa at give dem Meddelelse 
om det, inden han foretager en kirkelig Handling, og efter denne anmelde den til sogneprasten til Indforelse i Kirkebogen (20. 12.).

Dansk oplysningsvæsen - baade i skolen og under frie Former - syd for Grænsen har haft vanskeligere Kaar end Menighedslivet. Den danske Kommuneskole i Flensborg havde 1. 10. 242 Elever og den private Realskole i April 250 (Grb. S. (i5 og 80), men vilde have haft mange flere, hvis ikke Mynd'gliederne havde voldt vilkaarlige Vanskeligheder. Noget lignende er Tilfældet i Klus og Harreslev. (Grb. s. 71.). Baade her og i sist, Farup, Fruerlund, Munkbrarup, Jaruplund, Veding, Hyllerup, Langbjerg, Ellund, Østerby, Skovlund og Agtrup har man maattet norjes med Afholdelsen af danske Kursus (Grb. S. 85). I Aventoft indrettedes i December en dansk Privatskole med 20 Børn, der dog blev forbudt, fordi Læreren endnu ikke havde faaet den Tilladelse til at undervise, som han ansogte om (13. 12., 14. 12.). Et Landbrugsmøde, der 30. 1. holdtes i Valsbøl med Foredrag om Kartofler, blev forstyrret af Tyskerne, saa det maatte flyttes til en Gaardmands Stue.

I Slutningen af Januar købte »den slesvigske Forening i Gottorp Amt « for 40 Mill. Mk. Hotellet "Holsteinisches Haus" i Slesvig, kaldte det "S lesvighusu og indrettede en Forsamlingssal i det. Da der skulde holdes en Festlighed i det, truede Politiet med at lukke det (6. 3.).

Til Statte for dansk Kulturarbejde af den her omtalte Art blev der paa den danske $F$ in an slo v bevilget 200,000 Kroner, hvoraf 119,700 til $»$ Dansk Skoleforening for Flensborg og Omegn, 50,000 til Hojskoleunderstøttelser og Resten til Bogsamlinger, Me- 
nighedsarbejde, Sygepleje o. 1. (19. 3., 20. 3., 9. 4.). Som Modtræk foreslog de tysknationale i den preussiske Landdag at bevilge et Beløb til "Bevarelse af tysk Sprog og Kultur i det afstaaede Nordslesvig“ (31. 3.).

De mest haardhændede Udslag af $t \mathbf{y s k}$ Tvangs lys t var Forfølgelsen mod Advokat Ravn i Flensborg, der den 8. 1. blev afskediget som Notar, fordi han havde været med til at modtage den franske Krydser »Le Marseillaise«. Senere forsøgte man endog at fratage ham Retten til Sagforervirksomhed (Grb. 238-44.). Efter et Aars Forløb fik han dog omsider sin Ret ved Dom af den til Rigsretten i Leipzig knyttede Aresret 12. 1. 1924. Dette Angreb mod Advokat Ravn blev endog tyske Blade i Nordslesvig for groft. "Apenrader Tageblatt" misbilligede det (13. 7.).

Den 1. Marts blev Redaktør Oldsen i Nibøl idømt 14 Dages Fængsel for Fornærmelse mod de tyske Lærere.

Endnu skal nævnes, at det danske A a r s m ød e afholdtes i Flensborg den 9. 9. og var besøgt af (6000 Mennesker. Den slesvigske Forening havde ved den Tid 5(i33 Medlemmer i Flensborg. (10. 9.) 2100 paa Landet. Den slesvigsk-frisiske har omtrent 1000 og Foreningen i Gottorp Amt over 800. (Grb. S. 143-150.)

De tyskskrevne danskvenlige Blade blev 22. 11. indtil videre forbudt af Militæret og forst frigivet hen i 1924 .

\section{Politik.}

Paa det politiske Omraade har For berede lserne til Valget i 1924 spillet Hovedrollen. Allerede den 1. Februar opstillede Venstres Organisation i Løgumklosterkredsen den konstituerede Amts- 
forvalter i Sønderborg C. O. Pedersen, som sin Kandidat, efter at $\mathrm{N}$. J. Gothardsen havde frabedt sig Genopstilling. (2. 2., 12. 2.)

I Marțs blev Amtsforvalter Pedersen desuden ved et Delegeretmøde i V. Sottrup med 29 af 36 Stemmer opstillet i Sønderborgkredsen (20. 3.)

1. August opstilledes tidligere Landdagsmand $\mathrm{Nis}$ Nissen, Viby, som de radikales Kandidat i Sønderborgkredsen, senere ogsaa i Røddingkredsen (17. 12).

19. September opfordrede en Kreds af Venstrevalgere fhv. Minister $H$. P. Hanssen i Aabenraa til at stille sig som Venstres Kandidat i Haderslev og Aabenraakredsene. Den 26. 9. lovede han dette.

I Tonder opstillede Venstres Valgraad 26. 10. med 31i St. mod 24 N. J. Gotthardsen, Normark, som Kandidat. Imidiertid erklærede de 24 delegerede af Flensborgvenstre at ville virke for, at Stemmerne kastedes paa Amtsforvalter Pedersen, som de vilde have opstillet ogsaa her. (19., 20., 22., 24. 10., 5., 6., 7., 9., 11. 11.)

For denne sidstes Valg var ogsaa konservative Vælgere virksomme. Blandt de Navne, der fandtes under en Henvendelse til Gotthardsen om at være med til at virke for Valget af $\mathrm{C}$. O. Pedersen, fandtes blandt mange andre konservative ogsaa Gaardejer P. Tønder fra Birkelev. Han har imidlertid nægtet at have skrevet det eller at have givet Lov til at underskrive det. (23. 11., 28. 11.)

Amtsforvalter Pedersen vakte nogen Opsigt ved paa et Mode i Rurup den 20. 10. at udtale, at det var et Ledemotiv for hans Politik, at Jessens Fane skulde rejses igen (1. 11.) og endnu more, da han i Flensborg 
Avis 16. 12. erklærede: "Vi Flensborgmænd vil i Mocsætning til H. J. C. og de andre Aabenraamænd fore Kampen akkurat som for 1914; men dertil horer ogsaa Støtte af de nationalpolitiske Bestræbelser ${ }^{2}$ (17., 18., 19., 20., 21., 22., 29., 31. 12.).

Ved Venstres Delegeretmode i skive holdt H. P. Hanssen et Foredrag om de politiske Forhold i Sonderjylland (2. 12.)

Paa et Møde i Tinglev 17. 11. udtalte Venstremænd af begge Retninger Ønsket om at søge bort fra det skillende i Grænsestriden som Grundlag for det kommende valg. (19. 11.)

\section{Socialpolitik.}

Ogsaa i 1923 er der bleven udstykket en DeI D omæn ejord til Husmandsbrug, og anclet er taget i Udsigt til Udstykning saa snart som muligt 29. 1., 5. 3., 31. 5., 29. 8., 27. 9., 29. 10.) Af Præs tega a rdsjord er der derimod ikke udstykket synderligt. Det vil ogsaa næppe ske i nogen storre [نlstrakning, da Sognene, der har Ejendomsretten til den, ikke vil skille sig af med den, men derimod nolk ved Kirkearvefreste lade den komme de mindre Birg tilgode (26. 10.) Ved et sendemandsmøde i Tonder 26. og 27. 5. havde de sønderjydske Husmandsforeninger gjort Indsigelse mod en af Bestemmelserne vedrørende Præstegaardsjorden. Ved samme Møde talte H. P. Hanssen om Jordfordelingen i Sønderjylland (29. 5.)

Ogsaa paa købt Jord dannedes der en Del nye Husmandsbrug, f. Eks. ved Aarup (10. 4.)

Ordningen af Forsikringsnævnet er omtalt under »Grænsen«. 


\section{Erhverv og gkonomi.}

\section{a) Landbruget.}

Selv om Forholdene har været vanskelige $\mathrm{fol}^{*}$ Hovederhvervet, Landbruget, har det dog gode Frenıskridt at notere. Kvæ $\mathrm{g} b$ e s t and e n, og især Svinebesætningerne er i Vækst (1. 3.) I sidste Halvdel at Februar firedobledes Kvagudforslen til Tyskland (1. 3.). Dog holder den sig vel næppe paa den Højde. Mælkemængden er vokset med 20 pCt. fra 134 til 1 (it Millioner $\mathrm{kg}$, eller pr. Ko fra 1750 til $2100 \mathrm{~kg}$. Ogsaa i Kvaliteten er der saa gode Fremskridt, at den nu næermer sig det øvrige Land (9. 3.) Der var i Januar 14 Kontrolforeninger, mens kun et „Par af dem, der fandtes her tidligere, havde overlevet Krigen (26i. 1.) Antallet stiger stadig (19. 3.)

Andelssuineslagteriet i Aabenraa, der begyndte sin Virksomhed i Begyndelsen af December" 1922, var i Februar 23. oppe paa en Slagtning af ontrent 400 Svin om Ugen. I Sønderborg købtes del Grund til et 26. 2. Ogsaa i Graasten er der sat et Slagteri i Gang. I Haderslev bygges et Privatsvineslagteri, og mange andre Steder er der Planer on Slagterier.

Betydelige Arealer har været taget ind til s u kk er roed y rkn ing. Paa Haderslevegnen tegnedes 19. 2. 300 ha. Ogsaa paa Als og Sundeved dyrkes der Sukkerroer, der nu med Færgen fra Mommark føres til Faaborg. Der har her været Tale om Oprettelse af Saftstation (24. 10.)

Arealbenyttelsen er iøvrigt en Del anderledes her end norden Aa. Kornarealet er her kun 27,6 pCt., mens det i det ovrige Land er storre, helt op til 43,7 pCt. paa. Lolland-Falster. Alligevel har 
Sonderjylland over 10 pCt. af hele Danmarks Hvedeareal. Ogsaa Rodfrugtarealet er lille hernede, 11,7 pCt., mens den mindste Procentdel i det øvrige Land er Aalborg, Hjørring og Thisted Amter med 16 pCt. Derimod udgør Græsarealet her 36,8 pCt. mod 20 pCt. i Jylland og 8,3 pCt. paa Øerne.

Der er i 1923 gjort et stort Arbejde for For b ed r ing af store $L$ and s trækninger. Der er saadedes udarbejdet og vedtaget en Plan til Afvanding af Nin0 ha ved Tonder, hvoraf (i00 ligger under Kote Nul, ג. v. s. under Middelvandstanden i Havet, der er omtrent midt imellem $\mathrm{H} ø \mathbf{j}-$ og Lavvande. Udførelsen af denue Plan vil koste $3^{3}$ Millioner Kroner. (23. 1., 10. 3., 17. 4., 10. 12., 15. 12., 17. 12.) I 1922 udførtes der i hele Landet 287 Kultiveringsarbejder paa 1512 ha, 97 Vandløbsreguleringer, omfattende $4001 \mathrm{ha}$, og der oprettedes 25 nye Mosestationer og førtes Tilsyn med 37 celdre. (14. 7.) En meget stor Del af dette Arbejde falder paa Tønder Amt, hvor næsten Halvdelen af Arealet trænger til Afvanding (19. 4.) Flere Steder er der dannet Hededyrkningsselskaber (3. 7.) I 1922 afholdtes der af Fælleslandboforeningen 17 Markudflugter og (i4 Markforsøg samt Kalktrangsundersøgelser paa li5 Ejendomme og en Række Dyrskuer og Planteavlsudstillinger (19. 3.)

Paa Rømø lykkedes det at faa en Rest af Fællesskabet, det saakaldte "Aarty" afskaffet. Det bestod i, at Evret opgaves fra 1. Oktober til 10. April og var efterhaanden bleven en slem Hindring for rationel Ednyttelse af Jorden (6. 4.)

I Lobet af 1923 er der arbejdet paa Bygningen af et $\mathrm{H}$ a v i $\mathrm{g}$ e ved Rejsby, der skal lukke for det sidste Stykke af Sonderjyllands Fastland. Som Følge 
af den voldsomme Stormflod 30. 8., hvorved 19 Mennesker mistede Livet ved Rejsby Sluse, og mange efterfølgende Stormfloder, maatte Fuldførelsen af Diget midt i November opsættes til Foraaret (9. 11.) Oversvommelsen 30. 8. voldte alene i Tønder Amt Skade for 151,000 Kroner paa Mark og Eng foruden 141,000 paa det ikke fuldtfærdige Dige ved Rejsby (9. 11.)

Der er nu ogsaa planlagt et Dige om Nordøsthjørnet af Romø til Beskyttelse af 624 ha Eng-og Agerland, mens samtidig et reldre Dige ved Sydspidsen skal istandsættes og forhøjes. De vil tilsammen koste $1,085,000$ Kroner.

\section{b) Industri og Haandværk.}

Det største industrielle Foretagende, der efter Genforeningen er sat i Værk i Sønderjylland, er Landsdelens E l e k tricitetsforsyning. Der er bygget 270 Transformatorer (6. 8.), og 5. 9. lagdes Grunden til Hojspændingsværket i Aabenraa, der forelobig indrettes til $4200 \mathrm{Kw}$, men kan udvides indtil $20,000 \mathrm{Kw}$. Der var allerede i Begyndelsen af Aaret 10,000 Andelshavere $\mathrm{i}$ det. Centralen vil koste 2,2 og Fordelingsanlægget 10,7 Millioner Kroner (27. 2.)

Et Selskab, der var dannet til Forsyning af Haderslev Næs, opløstes i 1922, men 23. 1. 23. nedsattes et Udvalg til Dannelse af et nyt Selskab (23. 1., 15. 2.) 30. November indgik Midtsønderjyllands Elektricitetsforsyningsselskab som Andelshaver i Højspændingsværket.

Nogen Vanskelighed voldte Forholdet mellem Haderslev By, der valgte at udvide sit eget Elektricitetsværk, og Højspændingsværket (25. 1., 27. 9., 28. 9.), indtil der endelig sluttedes Forlig (9. 10.) Ogsaa Sanderborg har udvidet sit Vark. 
B y g g e r i e t har været livligt (3. 3., 13. 6., 24. 11.) Navnlig er der bleven bygget meget i Byerne, hvis. Indbyggerantal er vokset stærkt. Som Følge deraf har flere Grene af Industri og Haandværk haft gorlt med Arbejde, og Arbejdslosheden ikke været stor (6. 7.)

\section{c) Handel og Skibsfart.}

Handelen, der i 1922 led en Del under Prisfallet, har tydeligt nok haft bedre Kaar i 1923. Baade Bybefolkn'ngens Vækst og stigende Indtægter tyder paa, at $\mathrm{H}$ and e $\mathrm{l}$ e $\mathrm{n}$, der ved Siden af Industri og Haandværk er deme Befolkningsdels vigtigste Erhverv, naa have bedret sig. Mens det endnu i Februar f. Eks. kunde siges, at Indtagterne i Haderslev var starkt vigende (19. 2.), har det senere vist sig, at Skatterne kom saa godt ind, at Halvdelen af Januar Krartal 1924 kunde eftergives, og der var endda et stort $\mathrm{B} r$ lob tilovers (24.12.) til Trods for, at Krav om store Besparelser f. Eks. ved St. Severinskolen (4. 4.) lodes uænsede. En storre Begivenled i Forretningslivet var det, at 477 Aktionærer $i$ "Det sønderjydske Kompagni« trak sig ud af dette med et Aktiebelob af 1,009,000 Kr., hvorefter der i dette Selskab kun findes 344,000 Kr. sønderjydsk Kapital indskudt, mens (\%. K. har $4 \%$., Million. (21. 3., 24. 5., 16. 8.)

Sejladsen paa de sonderjydske Havne har vist god Stigning (12. 4., 29.12.), skønt de paabegyndte Havneudvidelser med Undtagelse af Graasten og Lonsemaj endnu langt fra var færdige ved Aarets Udløb.

In d b y g g e ra n t a 11 e t i Byerne er som navnt vokset: i Haderslev med 500, mod 100 i 1922, Tonder med 371, Sønderborg 590 og Aabenraa 506 (22.11., 24. 11., 12. 12., 18. 12., 31. 12.) 


\section{d) Pengeforholdene}

har i Aarets Løb vist Tegn til voksende Bedring. Folkebanken for Als og Sundeved har haft et tilfredsstillende Aar og giver $7 \sigma_{n}$ Udbytte (26. 2.). Haderslev Bank ligeledes, Indskuddene i den er vokset fra $8,119,365$, til 9,197,996 $\mathrm{Kr}$. (3. (i.). Den nordslesvigske Folkebank har haft et jævnt godt Aar. Indskuddene er vokset med $100,000 \mathrm{Kr}$. (12. 13.). Tønder Landmandsbank har arbejdet godt. Den giver ligesom Haderslev Bank 6 o $\%$ Udbytte (19. 3.). Industri- og Landmandsbanken i Haderslev maatte imidlertid likvidere med et Underskud af 70,000 Kroner. Hele Aktiekapitalen er tabt (22. (6).).

Nordslesvigsk Kreditforening afsluttede $\sin$ Likvidation med et Underskud af $40,000 \mathrm{Kr}$. (20. 8., 22. 8., 27. 8., 28., 8.).

Et haardt Slag var det for mange, navnlig smaa Hjem, at de samvirkende sønderjydske Brugsforening med 10 Filialer brod sammen og maatte likvidere med $75,951 \mathrm{Kr}$. Underskud, saa at hvert Medlem maatte indbetale $120 \mathrm{Kr}$. (2. 6., 28. 11.).

Paa Valutakonferencen gav Bankdirektør Hübbe en indholdsrig Oversigt over den økonomiske Udvikling i Sønderjylland siden Genforeningen (23. 8. Grb. ง. 313-348).

\section{e) Samkvem.}

I Løbet af 1923 er J e r n b a nernes Køreplaner udvidet saa stærkt, at vi fik omtrent normal Køreplan, ogsaa paa Amtsbanerne, der har fortsat Overgangen til Motordrift, som nu synes at virke tilfredsstillende i Haderslev Amt, hvor den er stærkest udviklet. Haderslev Amtsbaner bragte, til Dels som Følge deraf, i 1922/23 deres Underskud ned til 139,000 
Kr. (7. (j.). De alsiske Smaabaner vil nu ogsaa gore Forsøg med dem (22. 8.). Bilruterne er ved de nye Love bleven en Del indskrænket, idet Ruter, der maatte anses for overflødige, er bleven standset. Alligevel findes der over 30 Rutebiler i Haderslev Amt (22. 8.).

Den (i. 2. holdt den første Smaabane, den paa Als, 25 Aars Jubilæum, og samtidig gik det før'ste Tog: igennem til Mommark Færgeleje (6. 2., 7. 2.). Denne Færgerute har udviklet sig godt (22. 3., 11. (i.). I Efteraaret maatte Frergegaarden udvides (1. 11.) og trods den strenge Isvinter har den kunnet holdes i Gang til nu, 16. 2. 24. Ogsaa paa Lillebæltsoverfarten Aarøsund-Assens er Færdslen stigende (28. 3.). Den har dog haft større Vanskeligheder med Isen.

Mod Slutningen af Februar offentliggjordes den sønderjydske Banekomnissions Betænkning (22. 2.), og 7. 11. forelagde Trafikministeren paa Grundlag deraf Forslag om Baner fra Taps til Haderslev, Vejen -Gram, Sønderborg-Mommark, Vojens-Ribe, Rødekro-Logumkloster og en Bro over Alssund (21i. 2.) til en samlet Udgift af 19,4 Millioner Kroner. Disse Forslag drøftedes i Folketinget 27. 11., hvor M nisterem anbefalede dem. Imidlertid rejstes der paa flere $\mathrm{M \sigma}$ der omkring i Landet en Del Anker imod dem. Store Strækninger af Statsbanerne er bleven forbedret siden Genforeningen. Der er lagt Sveller paa 29 og nyt Spor paa $13 \mathrm{klm}$, udkørt $50,000 \mathrm{kbm}$ Ballast og. skaffet 100 nye Boliger tilveje (13. 8.).

Den haardt tiltrængte Forbedring af Lande ve je ne er fortsat i 1923. Alene i Tønder Amt var der indtil Foraaret siden Genforeningen bygget 40. klm ny Chaussé, og 90 af de tidligere $115 \mathrm{klm}$ var 
nybelagt (20.4.). Dette Arbejde er senere iovrigt fortsat paa de forskellige Egne, af Landet.

En Bro ved Hejlsminde blev indviet 20. 9 .

Det Arbejde, der vel nok har tildraget sig storst Opmærksomhed, navnlig i Byerne, er Forbedringen af Havnene. I Haderslev var Opfyldningen ved Havnen og Uddybningen af Havn og Fjord til $1,5 \mathrm{~m}$ færdig i Forsommeren (23. (i.). Der er siden arbejdet videre paa Havnepladsen. Allerede i 1922-23 har denne Havn vist sig mere rentabel end ventet. Dens Indtægt, der var budgetteret til 50,000 Kroner. gik op til 118,401 Kroner (29. 12.).

I Graasten blev den $5 \mathrm{~m}$ dybe Havn frerdig og indviet 22. 9. Det var den forste, der blev gjort faerdig. Ved Lønsemaj er der bygget en Skibsbro, der indviedes 7. 8., og ved Mommark er der som før nærnt taget en Færgehavn i Brug (6. 2.). Det storste Havneanlæg er det ved Aabenraa, der blev paabegyndt i Foraaret (23. 3., 12. (i., 22. 6.). Den faar $450 \mathrm{~m} \mathrm{ny} \mathrm{Kaj.}$ med 15 ha Landareal og 7,5 $\mathrm{m}$ Dybde. Selv for Tænders Vedkommende er der i Forbindelse med Afvandingsplanen bleven fremsat en Plan om et Sejllob og en Havn (7. 12., 19. 12.).

I Foraaret begyndte Tyskerne at bygge en $\mathrm{D} æ \mathrm{~m}$ $n$ ing fra Klangsbøl til sild, hvortil Færdslen fra Tyskland foreløbig gaar over Højer i plomberede Vogne paa Strækningen fra S. Løgum til Højer (14. z., 14., 7.). Stormfloden 30. 8. gjorde imidlertid saa stor Skade paa det paabegyndte Arbejde, at det senere har maattet standses indtil videre.

Ved Indvielsen af Telegraf- og Telefonstationen $i$ Haderslev 23. 4. oplystes det, at der 1. 4. var $6729 \mathrm{Te}-$ lefonabonnenter i Sønderjylland mod 3514 ved Genforeningen. 


\section{Kommunale Forhold.}

Af kommunale Forhold skal følgende næevnes. Mens der ellers de andre Steder var opnaaet Enighed om Byernes Udskillelse af Amterne, skete det for Haderslevs Vedkommende først i sidste Øjeblik (25. 9., 1. 10.). Christiansfeld derimod bliver foreløbig ved Amtet (17. 1.).

Haderslev, der ikke vil slutte sig til Højspæn(lingsværket, udvider sit eget Værk med en $800 \mathrm{He}$ steskrafts Dieselmotor (14. 3., 3.5.) og kom under sin Stræben efter at udvide sit Leveringsomraade i Strid med Højspændingsværket (20. 7., 27. 9., 28. 9., 9. 10.). Ogsaa Sønderborg Elektricitetsværk faar en ny Motor og dermed en Ydeevne af $1800 \mathrm{H}$. K. (21. 9.).

I Haderslev voldte Planen om en Pavillon i Damanlægget paa Klostergrunden stor Strid (21. 2., 7. 3, 2. 7., 7. 11.). Fra Byens Opland fremkom der i Marts Anker over, at den brød Forbindelsen med dette baade i Slagteri-, Elektricitets- og Banesagen (2. 3.).

Sønderborg By købte 6. 6. et Statsareal ved Havnen for 568,000 Kroner.

\section{Menighedslivet.}

Den 4. Januar døde den konstituerede Biskop over Haderslev Stift, Provst Nissen i Haderslev, der var opstillet som Kandidat til det forestaaende Bispevaly (4. 1.). Provst Hjortkjær i Sommersted blev nu fra grundtvigsk Side opstillet i hans Sted (12. 1.) Ved Valget fik han imidlertid kun 429 Stemmer, mens 655 faldt paa Professor Ammundsen (30. 1.), som derefter blev (2. 2.) udnævnt til Biskop i Haderslev, mens Stiftsprovst Olesen i Ribe, der var valgt med 766 Stemmer mod 732, som faldt paa den grundtvigske Kandidat, Provst Schultz-Lorenzen, udnævntes til Biskop i Ribe 
(2. 2.) Efter at alle de nyudnævnte Bisper var bleven ordinerede $\mathrm{i}$ København 25. 2., tiltraadte Biskop Ammundsen sit nye Embede 15. 4., Olesen noget før. Provst Hjortkjær udnævntes senere til Stiftsprovst og blev 8. 7. indsat som Præst i Gl. Haderslev. 4. 7. afholdtes i Haderslev Frue Kirke det første Landemode i det nye Haderslev Stift.

I Begyndelsen af Aaret var der Tale om Udarbejdelse af en Overgangs almebog, og det meddeltes, at et Udvalg var nedsat til at udarbejde den (3. 1.) Forsaavidt som der er Tale om en Salmebog, der skulde danne en Overgang til den, der bruges i det øvrige Land, vakte Meddelelsen vist ingen Steder i Sønderjylland nogen Glæde. Et enkelt Menighedsraad - i Haderslev Frue Sogn - bad Kirkeministeriet om at udsætte Sagen. Denne var dog nok fremtvungen af Grunde, der hang sammen med, at Konsistoriet i Kiel havde Ejendomsretten til Salmebogen. Siden har der ikke offentligt været Tale om den Sag. (24. 1.)

Den 23. September holdt Frimen ig h e d e r n e deres Aarsmøde i Bovlund under god Tilslutning.

I Henhold til den nye Kirkelovgivning har Kirkemin'steriet fastsat Regler for $\mathrm{K}$ irkens Best $\mathbf{y}$ relse, hvorefter denne for selvejende Kirkers Vedkommende bestaar af Menighedsraadet alene.

I Februar dannedes der en Forening af Menighedsraadsmedlemmer med Pastor Dahl i Egen som Formand (26. 2.)

Nogen Opmærksomhed vakte det i Foraaret, at Pastor Christiansen i Tyrstrup, en af de tyske Præster, der ved Men'ghedsafstemningen havde faaet Flertal, havde besluttet sig til at søge Kald i Tysk- 
land, efter at han havde faaet sine okonomiske Forhold saadan ordnet, at han i Stedet for Pension fik en Affindelsessum paa 15,000 Kroner (26. 4., 2. 10.) Søndag den 14. Oktober holdt han Afskedsprædiken (9. 10.)

\section{Oplysning.}

I Sønderjylland findes der i Folkeskolen 682 Lærere og Lærerinder, deraf 417 med dansk og 265 med tysk Lddannelse (10. 3.) I Foraaret besøgtes de danske Skoleafdelinger af 24,221 Børn, de tyske af 2,774. (S. Aarb. S. 157).

Nogle -Endringer $i$ den sonderjydske $\mathrm{Sk}$ olelov blev der fremsat Forslag om 28. 2. (11. 4., 12. 4.)

Af Re a l s k o l e r er der i 1923 oprettet én, nemlig i Løjt (8. 3.) og 31. 8. indviedes en ny t e $\mathrm{kn}$ is $\mathrm{k}$ $\mathrm{Sk}$ o l e i Haderslev.

Nye Folkeskoler er der b y g g e t flere af. I Burkal Sogn alene er der bleven bygget tre, nemlig i Burkal, Rens og Jyndevad. (1. 5.) De blev alle tre indviet 18. 5. En er bleven bygget i Ravsted (11. 12.), en tysk Folkeskole i Jejsing, en dansk i Rudbøl. I Haderslev paabegyndtes Bygningen af den ny St. Severinskole (8. 6.), som inden Aarets Udløb stærkt nærmede sig $\sin$ Fuldendelse.

I Anledning af Udnæwnelsen af en Viceskoleinspektør rejste "Haderslev St'ftstidende" en lang og hidsig Strid. (13. 3., 24. 3., 19. 4.)

Nye Forsamlingshuse er bygget i Københoved (i Stedet for Skrave, som er det ældste i Nordslesvig) (10. 10.) og i Højst (2L. 10.,) I Ravsted er et paabegyndt (22. 8., 17. 10.) I Abild vil Kroen blive omdannet til alkoholfri Beværtning med Forsamlingssal, i Højer er der købt Grund (1924) og sikret Kapital til et (11. 10.), og i Logumkloster vedtoges det 17. 10. at rejse Aktiekapital til et Forsamlingshus. 
Danebod Hojsk o le f:k i Juni en ny Forstander, Frede Terkelsen fra Herning (11. (i.)

26i. 8. holdt den sønderjydske skolefore $n$ ing Generalforsamling i Fredericia. Den havde støttet 270 fra Nordslesvig og 131 fra Sydslesvig t'l et Vinterskoleophold og henholdsvis 100 og 5 (i til Sommerskolen. Desværre var dens Medlemsantal taget af i Nordslesvig, mens det var vokset i det øvr'ge Land.

Sprogf ore $n$ ing e $n$ holdt Generalforsamling i Aabenraa den 30. 5. Ogsaa den har for faa Medlemmer, $1439 \bmod 5400$ i 1911 (5. 12.)

Det sonderjydske $L a n d s b i b l i o t e k$ aabnede 2. 1. sin nye Bygn:ng i Aabenraa. Det har i Aarets Lob sat 1500 nye Bøger ind i Udlaanet, som er stærkt stigende (30. 8.) I 1922 udlaante det 59,053 Bind (31.5.)

Et nyt Bibliotek er oprettet i Tønder (27. 1.) I Haderslev har Biblioteksforen:ngen dalende Aarsbidrag $1494 \mathrm{Kr}$. i $1922-23 \bmod 1779$ i $1921-22$. Den har nu 450 Medlemmer (17. 9.)

»Historisk Samfund for Sonderjyl1 a n d «, der var bleven dannet i December 1922, traadte med Udsendelsen af et Opraab i Virksomhed (8. 3.) efter at have holdt s.t første Bestyrelsesmøde 4. 1. Det holdt sit første Aarsmøde paa Urnehoved 15. 7. og udsendte 16. 7. 1. Halvbind af den ny Række af "Sønderjydske Aarbøger«.

\section{Retssager.}

Retssager af offentlig Interesse er jo nu kun sjældne. De, der vedrører økonomiske Forhold af almindelig Interesse, er en Del nævnt af under Omtalen af kkonomiske Forhold og Pengevæsen, ligesom andre 
er omtalt under de Rubrikker, de hører hjemme i. Her skal endnu kun nævnes et Par af de Retsskandaler, der strakte s'g ind i 1923.

Den 26. 2. blev Overretssagfører Mikkelsen i Aabenraa ved den derværende Underret idømt 1 Aars Forbedringshus og for bestandig frakendt Retten til Sagforervirssomhed (26. 2. 28. 2.) Før Dommen faldt, blev der deponeret $25,000 \mathrm{Kr}$. mod at Strafansvar frafaldtes (1. 3.)

Den 25. 4. stadfæstede Højesteret Dommen over Dommerfuldmægtig Hjardemaal, som 10. 6. begyndte Afsoningen af de 8 Maaneders Forbedringshus.

Statsadvokat Holm fra Sønderborg udtaler ved Lejlighed, at Kriminaliteten j Sonderjylland har bedret sig i forbavsende Grad og nu ikke er nævneværdigt større end $\mathbf{i}$ det øvrige Land (10.12.).

\section{Pressen.}

Paa "Modersma a l e t«s Generalforsamling 22. 3. skaffede Flensborggruppen blandt Aktionærerne sig Herredømmet i D'rektion og Tilsynsraad med en Stemmes Flertal (23. 3., 31. 3.) Den afviste alle Forslag til Overenskomst. De ovrige Aktionærer besluttede derfor 7. 5. at udgive et nyt Venstreblad under Navn af "Haderslev Amtstidende" til 1. Juli (10. 4., 22. 5.) Redaktørerne Lebeck og Petersen blev afskediget fra "Modersmaalet" (14. 4., 17. 4., 15. 5., 16. 5.) Til Redaktør af det nye Blad valgtes $H$. J. Rud (8. 6.) Det begyndte at udkomme 1. 7. (5. 12., "Striden om Dannevirke« 1923.)

Redaktør Hamann ved "Neue Tondernsche Zeitung “ blev 23. 3. ved Underretten idømt 4 Maaneders Fængsel for Fornærmelse mod den danske Dommerstand. Denne Dom blev 5. 5. stadfæstet af Lands- 
retten, men blev 9. 10. af Højesteret nedsat til en Bøde paa $2000 \mathrm{Kroner}$.

\section{Personlige Sager.}

Af kendte Mænd døde i Aarets Løb Provst Nissen i Haderslev, 4. 1., Fabrikant B. F. Bastiansen fra Aabenraa (i Breslau) 26. 1., Rentier Jørgen Iversen i Svejrup 11. 5., Dr. phil. P. Lauridsen (født i Jægerup) i København 14. 5., Gaardejer J. P. Jensen i Lovrup 4. 7., Pastor Wulff, Roager 21. 9., fhv. Borgmester Th. Møller i Haderslev 17. 9. og Rentier Th. Ries i Aabenraa 20. 11.

I Oktober kom endnu en af de sønderjydske Krigsf anger, Hørlück fra Varnæs, hjem fra Sibirien efter 8 Aars Fangenskab (22. 10, 26. 10., 3.11.)

Den bekendte tidligere Amtsforstander P. K i e r fra Sønderborg prøver paa at tiltvinge $s^{\prime} g$ dansk Indfødsret (6.12., 11. 12.)

\section{Andre Sager.}

Af Sager og Begivenheder, der ikke har kunnet føjes ind under de bragte Overskrifter, skal endnu nævnes følgende:

18. 2. foranstaltedes en Blindeudstilling i Aabenraa, der gav et Overskud af 5307 Kroner.

2. 3. brændte Dybbøl Præstegaard.

Om Mos e f u n d e t fra Hjortspringskobbel gives Oplysning (6. 3., 23. 4.)

D y b bøl B a n k takseredes til Fredning (6. 4.) Finansudvalget foreslaar $107,000 \mathrm{Kr}$. anvendt til det, og Sønderborg Amt giver 53,000 Kr. (12. 4., 28. 6.) afsagde Overfredningsnævnet Kendelse i Sagen.

Nogle Skovpartier paa forskellige Egne er bleven f red et (9. 4., 3. 7.) Men der mangler Midler til 
Fortsættelse af Fuglefredningen paa Øen Jordsand (9. 4.) Ved Munkemsllebugten er 40 ar Skov bleven fredet (30. 4.)

For Bevarelsen af $\mathrm{M}$ inder fra Fortiden og Oplysning om denne er der gjort en hel Del i Aaret, der svandt. Stuehuset paa Stenderupgaard i Grarup Sogn blev opmaalt og tegnet for Ombygningen (12. 4.). Ligeledes er en Del gamle Huse paa Als bleven undersøgt (13. 6.) I Anlægget paa Damnæsset i Haderslev blev nogle gamle Ruiner udgravet og undersogt (16. 4.) Ved Roager er en By fra Jernalderen bleven funden og til Dels undersogt (27. (i.) I Løjt og i Aabenraa Landsogn er der kortlagt 11i7 Oldtidsminder. Nogle af dem er til Dels undersngt og enkelte fredlyst (28. 7., 3. 8., 8. 8., 16. 8.) ITonder er der ved Kloakeringsarbejder fundet Rester af Graabrodreklostret (?) (4. 10.). 28. 11. holdt Logumkloster 750 Aar's Jubilæum for Klostret.(28. 10., 27. 11., 29. 11.) 12. og 13. August holdt Christiansfeld 150 Aars Jubilæum.

Dr. Achelis i Haderslev fandt i Byens Arkiver en Samling Digte af Knud Bramsen fra 1570 (8. 6.) og i Hospitalet et Kaldsbrev fra 1524 fra Hertug Kristian til Jens Sørensen. i "Odensbæck" (2. 7.) P. El'assen fremdrager en Del gamle Retsforhold fra Rødding (20. 6., 21. 6., 30. 6., 2. 7., 11. 7., 23. 7.) og Skodborg (27. 7., 28. 7.) Achelis ligeledes fra Haderslev (25. 8., 13. 9., 18. 10., 21. 11.) og H. P. Hanssen offentliggjorde nogle Dagbogsoptegnelser fra Krigstiden (23. 6., 6. 7., 25. 7., 26. 7.) I Aabenraa dannes et Arkivdepot (25. 10., 26. 10., 27. 10.). Til dette skal Arkivalier fra Sønderjylland afleveres (13. 12.). 2. 12. holdtes i Aabenraa en Hjemstavnsaften, hvor mange Træk af Byens Historie blev fremdraget (3. 12.) 
24. 5. holdt den nordslesvigske $\mathrm{K}$ vin defore n ing Generalforsamling i Aabenraa.

Ko ng e n besogte Haderslev, Aabenraa, Tønōer og Grænseegnene (30. 5.) og Sonderborg, Augustenborg og Graasten (1ti. 8.) Den 28. 9. fandt en Kongerevy Sted ved Stepping.

Diget ved $\mathrm{H}$ ø je $\mathbf{r}^{2}$ forhøjedes omtrent ${ }^{1}: \mathrm{m}$ (18. 6.)

Ved Braines i Frankrig indrettes en sønderj y d s k K i r k e ga a r d (22.6.)

20. 7. afsløredes $i$ Rørding et Mindesmærke for Morten Eskesen.

I Efteraaret sprængtes en Del af de tyske Befæs t n ingsan lag (15. 8.)

30. 8. hrergede en voldsom $\mathrm{S}$ t o r m f l o d Vestkysten, 9. 10. og 10. 10. igen. Hele Efteraaret igennem fulgte den ene Stormflod kort efter den anden.

16. 9. holdt "s on der jydsk I d r r t s fore $n$ in $g$ stort Jubilæumsstærne i Haderslev.

11. 12. holdt Frederiks k l u b ben i Aabenraa 75 Aars Jubilæum (10. 12.) 